\title{
PERSEPSI PENERAPAN WAJIB MILITER GUNA MENINGKATKAN PENDIDIKAN BELA NEGARA
}

\author{
Utari Maharani Noor ${ }^{1}$ \\ ${ }^{1}$ Pendidikan Vokasi, Bidang Minat Administrasi Hukum, Universitas Brawijaya, email: \\ utarimaharani21@gmail.com
}

\begin{abstract}
ABSTRAK
Pada Undang-Undang Dasar Negara Republik Indonesia 1945 mengatur bahwa warga negara Indonesia harus ikut serta dalam upaya pembelaan negara. Hal tersebut terdapat dalam pasal 27 ayat 3 yang berbunyi, "Setiap warga negara berhak dan wajib ikut serta dalam upaya pembelaan negara". Pengembangan sikap bela negara dapat dilakukan dengan beberapa upaya seperti halnya dapat memberikan pendidikan wajib militer yang sudah diterapkan di beberapa negara seperti halnya di Korea Selatan. Pelatihan dasar kemiliteran di Indonesia pasalnya hanya diberikan kepada para Tentara Nasional Indonesia yang pada hakikatnya merupakan suatu hal yang berhubungan langsung dengan profesi yang dijalani. Jurnal ini hendak menjelaskan bagaimana persepsi masyarakat jika penerapan wajib militer di Indonesia diadakan dan bagaimana bentuk pendidikan dasar militer yang sesuai dalam tingkat para pelajar, mahasiswa serta seseorang yang hendak terjun dalam dunia pekerjaan.
\end{abstract}

ARTICLE INFO

Kata Kunci:

Persepsi; pendidikan

dasar militer; bela

negara

\section{Cite this paper:}

Noor, U. M., 2020.

Persepsi Penerapan

Wajib Militer Guna

Meningkatkan

Pendidikan Bela

Negara. Widya Yuridika:

Jurnal Hukum, 3(1).

\section{PENDAHULUAN}

Dalam sejarah berdirinya Negara Republik Indonesia membutuhkan usaha yang keras, melihat Indonesia adalah negara yang kaya akan keberagaman. Keberagaman tersebut dapat dikalahkan dengan satu cara yaitu dengan bersatu tanpa mempermasalahkan tentang perbedaan yang terjadi dan lebih mengedepankan toleransi. Hanya rasa persatuan itulah yang dapat menyatukan bangsa yang besar ini. Seperti halnya para pahlawan yang rela berperang hanya untuk membela serta merebut kembali Indonesia dari tangan para penjajah. Perjuangan yang dilakukan oleh para pahlawan terdahulu adalah sebagai bukti bahwa membela tanah air ialah hal yang terpenting dalam menjaga negara kepulauan ini. Upaya bangsa Indonesia menyelenggarakan pertahanan keamanan dikukuhkan bersamaan dengan detik-detik Proklamasi 17 Agustus 1945. Jiwa teks proklamasi serta Pembukaan dan Batang Tubuh UUD 1945, semangat dan tekad 
bangsa Indonesia untuk membela dan mempertahankan tetap tegaknya Negara Kesatuan Republik Indonesia, menggambarkan wawasan dan pandangan hidup bangsa Indonesia tentang pembelaan terhadap negaranya. ${ }^{1}$ Pembelaan dan pertahanan itu membuahkan beberapa prinsip dasar bagi penyelenggaraan pertahanan keamanan Negara Republik Indonesia.

Pada awal kemerdekaan saat itu Indonesia belum memiliki organisasi militer dan rakyat hanya bergabung dalam laskar-laskar serentak memanggul senjata seperti PETA, HEIHO, KNIL yang insaf, Seinendan Keibodan, Gyugun, Suisyintai yang telah terlatih yang bersama-sama dengan rakyat melakukan perlawanan dengan mengangkat senjata. Hingga akhirnya muncullah Badan Keamanan Rakyat (BKR) yang sekarang telah berganti menjadi Tentara Nasional Indonesia (TNI). Disini TNI diajarkan bagaimana sikap dalam menyikapi musuh yang hendak mengancam keamanan negara serta membentuk karakter dengan menanamkan rasa cinta pada tanah air. Namun hal seperti itu tidak hanya diterapkan dalam dunia militer saja tentu saja rakyat Indonesia juga harus memiliki jiwa bela negara karena hal tersebut berkenaan dengan Undang-Undang pasal 30 ayat (1) yang mengatakan bahwa, "Tiap-tiap warga negara berhak dan wajib ikut serta dalam usaha pembelaan negara.". Melihat rasa cinta rakyat Indonesia terhadap negaranya belum sepenuhnya berhasil. Pemerintah hendak untuk mengusulkan tentang penerapan wajib militer agar dapat lebih menumbuhkan rasa bela tanah air serta membentuk karakter para generasi bangsa. Melihat beberapa negara di dunia telah menerapkan program wajib militer ini yang lebih diperuntukkan bagi laki-laki.

Dari perencanaan yang diusulkan oleh para pemerintah, muncul pertanyaan Bagaimana persepsi masyarakat mengenai rencana penerapan wajib militer di Indonesia? Tujuan dari penulisan jurnal ini untuk mengetahui bagaimana pendapat masyarakat jika diterapkannya wajib militer di Indonesia.

\section{TINJAUAN PUSTAKA}

\section{Persepsi}

Setiap orang tentu saja memiliki pandangan yang berbeda satu sama lain dalam melihat suatu hal. Perbedaan pendapat itu tentu saja akan menimbulkan penindaklanjutan dengan respon serta tindak yang berbeda. Pandangan yang terjadi inilah yang disebut dengan persepsi. Seperti halnya Sarlito W. Sarwono yang mendefinisikan persepsi sebagai berikut : "Persepsi adalah proses kategorisasi. Organisme untuk masukan tertentu (objek-objek di luar, peristiwa dan lain-lain), dan organisme itu berespon dengan menghubungkan masukan itu dengan salah satu kategori (golongan) objek-objek atau peristiwa. Proses menghubungkan ini adalah proses aktif dimana individu yang bersangkutan dengan sengaja mencari kategorisasi yang tepat, sehingga ia dapat mengenali atau memberi arti kepada masukan tersebut. Dengan demikian persepsi juga bersifat inferensial (mengambil kesimpulan)". ${ }^{2}$ Di dalam persepsi mengandung suatu proses dalam diri untuk mengetahui dan mengevaluasi sejauh mana

\footnotetext{
${ }^{1}$ Chaidir Basrie. 1998, Bela Negara : Implementasi dan Pengembangan (penjabaran pasal 30 UUD 1945). Jakarta: Universitas Indonesia Press, hlm. 4.

Sybilla Narasya, “Apa yang dimaksud persepsi?”, https://www.dictio.id/t/apa-yang-dimaksud-denganpersepsi/4669 diakses pada 07 Desember 201909.08
} 
kita mengetahui orang lain. Pada proses ini kepekaan dalam diri seseorang terhadap lingkungan sekitar mulai terlihat. Cara pandang akan menentukan kesan yang dihasilkan dari proses persepsi. Proses interaksi tidak dapat dilepaskan dari cara pandang atau persepsi satu individu terhadap individu yang lain, sehingga memunculkan apa yang dinamakan persepsi masyarakat. Persepsi masyarakat akan menghasilkan suatu penilaian terhadap sikap. Perilaku dan tindakan seseorang di dalam kehidupan bermasyarakat. $^{3}$

Di lain pendapat Wagner dan Hollenbeck (1995) menjelaskan sedikit dari persepsi yakni, "Ada sebuah pendapat dari Wagner dan Hollenbcek yaitu, We human beings have five senses through which experience the world around us: sight, hearing, touch, smell and taste." Menurutnya, setiap manusia dianugerahi dengan 5 indera yang mana dengan kelima-limanya dapat dimanfaatkan untuk merasakan dunia yang ada di sekitar. Mulai dari penglihatan, pendengaran, penciuman, perasa, serta pengecap. ${ }^{4}$ Definisi persepsi menurut Wagner dan Hollenbeck sendiri adalah sebuah proses yang mana seseorang tersebut dapat memilih, mengelola, menyimpan, serta menginterpretasikan informasi-informasi yang telah dikumpulkan melalui kelima indera tersebut.

Pendapat dari Indrajaya (1986) dalam Prasilika, Tiara H. (2007:10) berpendapat bahwa persepsi adalah proses dimana seseorang mengorganisasikan dalam pikirannya, memanfaatkan, mengalami, dan mengolah perbedaan atau segala sesuatu yang terjadi dalam lingkungannya. ${ }^{5}$

Dalam menentukan persepsi terdapat faktor-faktor fungsional yang berasal dari kebutuhan, pengalaman masa lalu, dan hal-hal lain yang dapat disebut sebagai faktorfaktor personal, yang menentukan persepsi bukan jenis atau bentuk stimuli, tetapi karakteristik orang yang memberi respon terhadap stimuli (Rakhmat, 1998). ${ }^{6}$ Dapat dikatakan bahwa pendapat dari Rakhmat ialah persepsi seseorang ditentutkan dari kebutuhan, pengalaman yang terjadi di masa lalu serta hal-hal yang berkaitan langsung dengan faktor personal seseorang.

\section{Pendidikan Dasar Militer}

Kata "militer" berasal dari kata "miles" yang dalam bahasa Yunani berarti orang yang bersenjata yang siap untuk bertempur, yaitu orang-orang yang sudah terlatih untuk menghadapi tantangan atau ancaman pihak musuh yang mengancam keutuhan suatu wilayah atau negara. ${ }^{7}$ Untuk menciptakan pasukan bersenjata yang terlatih perlulah pelatihan dengan memberikan pendidikan dasar militer yang merupakan suatu bagian pendidikan yang penting dalam dunia militer di Indonesia. Pendidikan dasar militer ini memberikan pembekalan kepada para calon tentara sebelum mengemban tugasnya sebagai Tentara Nasional Indonesia. Di dalam pendidikan dasar militer ini adapun materi yang diberikan seperti Cara Memberi Instruksi (CMI), Pengetahuan Senjata Ringan, Survival, Wawasan Kebangsaan, Pengetahuan tentang tataran Dasar Bela Negara,

\footnotetext{
${ }^{3}$ Rohmaul Listyana, Yudi Hartono,2015. “Persepsi Dan Sikap Masyarakat Terhadap Penanggalan Jawa Dalam Penentuan Waktu Pernikahan (Studi Kasus Desa Jonggrang Kecamatan Barat Kabupaten Magetan Tahun 2013)”. Jurnal Agastya, Vol. 5, No. 1, hlm. 121 - 122.

${ }^{4}$ Khanza Savitra, "10 Persepsi Menurut Para Ahli", https://dosenpsikologi.com/pengertian-persepsi-menurutpara-ahli diakses pada 07 Desember 201909.10

5 Ben Fauzi Ramadhan, 2009, “Gambaran Persepsi Literatur” Jakarta: Universitas Indonesia, hlm. 6.

6 Ben Fauzi Ramadhan, 2009, “Gambaran Persepsi Literatur” Jakarta: Universitas Indonesia, hlm. 8

${ }^{7}$ Moch Faishal Salam, 1994, Peradilan Militer Indonesia. Bandung: Mandar Maju, hlm. 14.
} 
Peraturan Baris Berbaris (PBB), Peraturan Penghormatan Militer (PPM), Peraturan Urusan Dinas Dalam (PUDD), Navigasi Darat dan lain sebagainya.

Pemberian materi mengenai pendidikan dasar militer ini berguna untuk menenangkan suatu pertempuran diperlukan mutlak suatu pengemandoan tunggal yang istilah teknisnya disebut "unity of command" yang artinya setiap bagian dari organisasi militer hanya seorang saja yang bertanggungjawab secara total mengenai segala hal ikhwal kesatuannya dan pelaksanaan tugasnya. ${ }^{8}$ Dengan demikian angkatan bersenjata setiap saat dapat menghadapi gangguan atau serangan yang diberikan atau datang dari pihak lawan, maka dari itu calon angkatan bersenjata harus dipersiapkan dengan matang secara terus-menerus, Dengan kesiapan yang matang tersebut untuk menghadapi ancaman yang datang, para angkatan bersenjata dapat dengan sigap melawan ancaman dari musuh karena bagaimanapun juga itu adalah beban kewajiban para angkatan bersenjata dalam pembelaan negara dan pertahanan negara.

Selain pemberian materi berupa pengetahuan senjata, sebagai tentara juga tidak terlepas dari yang namanya kedisplinan. Pemeliharaan kedisplinan untuk menjaga integritas angkatan bersenjata serta menjamin terlaksananya dan berhasilnya tugas militer yang sangat penting karena langsung berhubungan dengan tegak dan runtuhnya negara. ${ }^{9}$

\section{Bela Negara}

Bela Negara adalah sikap dan perilaku warga negara yang dijiwai oleh kecintaannya kepada Negara Kesatuan Republik Indonesia yang berdasarkan Pancasila dan Undang-Undang Dasar (UUD) 1945, dalam upaya mempertahankan kelangsungan hidup bangsa dan negara. ${ }^{10}$ Membela dan mempertahankan negara tidak hanya tugas dari pemerintah negara atau para Tentara Nasional Indonesia (TNI), sikap bela negara ialah hak, kewajiban serta tanggungjawab seluruh rakyat Indonesia, hal tersebut telah tercantum dalam Batang tubuh UUD 1945 Bab XII Pasal 30. Di sisi lain, Bela negara juga didefinisikan bahwa sebuah konsep yang disusun oleh perangkat perundangan dan petinggi suatu negara tentang patriotisme seseorang, suatu kelompok atau seluruh komponen dari suatu negara dalam kepentingan mempertahankan eksistensi negara tersebut. ${ }^{11}$ Dalam definisi ini dijelaskan bahwa bela negara mengajarkan tentang bagaimana cara mengembangkan serta menumbuhkan sikap patriotisme seseorang rakyat dalam mempertahankan negara. Dalam pelaksanaan pembelaan negara, seorang warga bisa melakukannya baik secara fisik maupun non fisik. Pembelaan negara secara fisik diantaranya dengan cara perjuangan mengangkat senjata apabila ada serangan dari negara asing terhadap kedaulatan bangsa. Sementara, pembelaan negara secara non fisik diartikan sebagai semua usaha untuk menjaga bangsa serta kedaulatan negara melalui

\footnotetext{
${ }^{8}$ Ibid., hlm. 15.

${ }^{9}$ Ibid., hlm. 16.

${ }^{10}$ Marolli, "Peringatan Hari Bela Negara 2017", https://kominfo.go.id/content/detail/12075/peringatan-hari-belanegara-2017/0/artikel_gpr Di akses pada 07 Desember 2019. 18.48
}

11 Setjen Wantannas, "Bela Negara : Pengertian, Unsur, Fungsi, Tujuan Dan Manfaat Bela Negara", https://www.wantannas.go.id/2018/10/19/bela-negara-pengertian-unsur-fungsi-tujuan-dan-manfaat-belanegara/ Di akses pada 07 Desember 2019. 18.49 
proses peningkatan nasionalisme. ${ }^{12}$ Dalam pengertian lain Pembelaan Negara atau Bela Negara bermakna bahwa tekad, sikap dan tindakan warga negara yang teratur, menyeluruh, terpadu dan berlanjut yang dilandasi oleh kecintaan pada tanah air, kesadaran berbangsa dan bernegara Indonesia, keyakinan akan kesaktian Pancasila sebagai ideologi negara, dan kerelaan untuk berkorban guna meniadakan setiap ancaman baik dari luar maupun dari dalam negeri yang membahayakan kemerdekaan dan kedaulatan negara, kesatuan dan persatuan bangsa, keutuhan wilayah dan yurisdiksi nasional, serta nilai-nilai Pancasila dan UUD 1945.1313 Pada umumnya pengertian pembelaan negara atau bela negara dipersepsikan identik dengan pertahanan keamanan. Hal ini dapat dimengerti, karena sejak awal berdirinya Negara Kesatuan Republik Indonesia, keikutsertaan warga negara dalam bela negara diwujudkan dalam kegiatan di bidang pertahanan keamanan. ${ }^{14}$

\section{METODE}

Jenis penelitian yang digunakan dalam penelitian ini adalah penelitian deskriptif yang menggunakan metode Penelitian perpustakaan merupakan kegiatan mengamati berbagai literatur yang berhubungan dengan pokok permasalahan yang diangkat baik itu berupa buku, makalah ataupun tulisan yang sifatnya membantu sehingga dapat dijadikan sebagai pedoman dalam proses penelitian. Menurut Kartini Kartono (1986: 28) dalam buku Pengantar Metodologi Research Sosial mengemukakan bahwa tujuan penelitian perpustakaan adalah untuk mengumpulkan data dan informasi dengan bantuan bermacam-macam material yang ada di perpustakaan, hasilnya dijadikan fungsi dasar dan alat utama bagi praktek penelitian di lapangan. ${ }^{15}$ Dalam penelitian ini menggunakan sumber data dari buku, internet, penelitian yang sudah ada sebelumnya serta tulisantulisan yang berkaitan dengan fokus penelitian sebagai penunjang dalam mengelolah penelitian ini.

\section{HASIL DAN PEMBAHASAN}

Ketahanan nasional adalah kondisi dinamis bangsa yang berisikan keuletan, ketangguhan, dan kemampuan mengembangkan kekuatan nasional dalam menghadapi dan mengatasi segala bentuk tantangan, ancaman, hambatan, dan gangguan, baik langsung maupun tidak langsung membahayakan integritas, identitas, dan kelangsungan hidup bangsa dan negara serta perjuangan nasional menuju kepada kejayaan bangsa. ${ }^{16}$ Dalam menjaga ketahanan negara merupakan salah satu kewajiban warga Indonesia sebagai bentuk pembelaan terhadap bangsa Indonesia. Kewajiban untuk membela negara sendiri telah tercakup dalam Undang-Undang Dasar yang masuk dalam pasal Pasal 27 ayat (3) mengatakan bahwa, Setiap warga negara berhak dan wajib ikut serta dalam upaya pembelaan negara". Serta kewajiban rakyat untuk melakukan bela negara juga

12 Setjen Wantannas, "Bela Negara : Pengertian, Unsur, Fungsi, Tujuan Dan Manfaat Bela Negara", https://www.wantannas.go.id/2018/10/19/bela-negara-pengertian-unsur-fungsi-tujuan-dan-manfaat-bela-negara/ Di akses pada 07 Desember 2019. 18.53

13 Chaidir Basrie. 1998, Bela Negara : Implementasi dan Pengembangan (penjabaran pasal 30 UUD 1945). Jakarta:Universitas Indonesia (UI-Press)., hlm. 8.

${ }^{14}$ Chaidir Basrie. Bela Negara : Implementasi dan Pengembangan (penjabaran pasal 30 UUD 1945). Universitas Indonesia (UI-Press): Jakarta. 1998, hlm. 12.

15 Idtesis.com, "DEFINISI METODE DESKRIPTIF", https://idtesis.com/metode-deskriptif/ Di akses pada 07 Desember 2019. 18.57

${ }^{16}$ H. Ton Kertapati. 1988, Ketahanan Nasional Indonesia dalam Penerangan Pembangunan. Jakarta: PT. Pradnya Paramita, hlm. 2. 
tercantum pada Undang-Undang Dasar Pasal 30 ayat (1) mengamanatkan bahwa "Tiaptiap warga negara berhak dan wajib ikut serta dalam usaha pertahanan dan keamanan negara". ${ }^{17}$ Dengan berpedoman pada Undang-Undang Dasar 1945, maka sudah seharusnya masyarakat Indonesia ikut berpartisipasi dalam menjaga keamanan negara. Penerapan bela negara dapat dilakukan dengan diadakannya wajib militer guna memberikan pendidikan kemiliteran dan pembentukkan karakter.

Landasan bela negara ialah wajib militer. ${ }^{18} \mathrm{Hal}$ itu dikarenakan dalam menjaga ketahanan suatu negara perlulah orang-orang yang memang memiliki keahlian dalam bidang militer, seperti halnya tentara yang merupakan anggota militer. Jika dipandang dari segi hukum, maka anggota militer mempunyai kedudukan yang sama dengan anggota masyarakat biasa, artinya bahwa sebagai warga negara, baginyapun berlaku semua ketentuan hukum yang berlaku, baik hukum pidana, perdata, acara pidana dan acara perdata. ${ }^{19}$ Dengan begitu peran masyarakat juga sama pentingnya seperti tentara hanya saja untuk anggota militer memiliki beban kewajiban yang lebih banyak daripada warga biasa dalam hal yang berhubungan dengan pertahanan negara, walaupun pada hakekatnya setiap warga negara wajib ikut dalam bela negara. Pentingnya bela negara membuat pemerintah berencana untuk mengadakan wajib militer, melihat di beberapa negara seperti Korea Selatan, Amerika Serikat, Jerman dan beberapa negara di dunia lainnya telah menerapkan pendidikan dasar militer ini. Seperti halnya pada tahun 2018, Anggota I BPK, Agung Firman Sampurna menyampaikan apresiasi terhadap pencapaian Kemenhan. Namun ia juga mengusulkan agar ada peningkatan pada Operasi Militer Selain Perang (OMSP) yaitu penerapan wajib militer (wamil). ${ }^{20}$ Namun merubah mindset masyarakat tidak semudah membalikkan telapak tangan melihatnya selama ini Indonesia tidak pernah menerapkan system wajib militer, lalu seketika pemerintah mengusulkan penerapan wajib militer untuk meningkatkan sikap bela negara masyarakat. Jika dilihat dari dulu Indonesia masih terfokus pada penanaman jiwa dan pemikiran sesuai dengan dasar negara Pancasila dan Undang-Undang Dasar 1945 ke benak masyarakat. Melihat negara maju seperti Korea Selatan dan negara lainnya yang sudah menerapkan system wajib militer ini, tentu hanya sekedar pemberian pembekalan berupa materi tidaklah cukup untuk membentuk seseorang namun dengan wajib militer seseorang dapat lebih mempraktekkan bagaimana bentuk bela negara yang benar.

Dalam ketentuan UU No. 20 Tahun 1982 yang dikaitkan dengan ketentuan UU No. 2 Tahun 1989 (UU Tentang Sistem Pendidikan Nasional), tentang Pendidikan Pendahuluan Bela Negara (PPBN) sebagai bagian dari system pendidikan nasional, merupakan upaya untuk menumbuhkan kesadaran bela negara dan langkah awal untuk mempersiapkan warga negara menunaikan hak dan kewajibannya dalam bela negara. ${ }^{21}$

\footnotetext{
17 Kemenkuham, "SEJARAH BELA NEGARA", https://www.kemhan.go.id/belanegara/sejarah-bela-negara Di akses pada 07 Desember 2019. 22.45

18 Setjen Wantannas, "Bela Negara : Pengertian, Unsur, Fungsi, Tujuan Dan Manfaat Bela Negara", https://www.wantannas.go.id/2018/10/19/bela-negara-pengertian-unsur-fungsi-tujuan-dan-manfaat-belanegara/ Di akses pada 07 Desember 2019. 20.50

${ }^{19}$ Moch Faishal Salam, 1994, Peradilan Militer Indonesia. Bandung: Mandar Maju, hlm. 15.

20 CNN, "BPK Usulkan Menhan Segera Terapkan Wajib Militer",
https://www.cnnindonesia.com/nasional/20190617140423-20-403904/bpk-usulkan-menhan-segera-terapkanwajib-militer di akses pada 07 Desember 2019. 22.49

${ }^{21}$ Chaidir Basrie. 1998, Bela Negara : Implementasi dan Pengembangan (penjabaran pasal 30 UUD 1945). Jakarta:Universitas Indonesia (UI-Press)., hIm. 14.
} 
Berdasarkan pengertian yang terkandung dalam Bab XII Pasal 30 UUD 1945 maka dasar pokok penyelenggaraan pertahanan keamanan Negara Republik Indonesia bertumpu kepada kesadaran warga negara akan hak dan kewajibannya. Kesadaran warga negara hanya dapat ditumbuhkan melalui penumbuhan motivasi kecintaannya pada tanah air dan motivasi keikutsertaan dalam pembelaan negara. ${ }^{22}$ Dengan bergantinya zaman yang semakin modern, banyak para generasi muda yang lalai akan sejarah dan perjuangan para pahlawan dalam mengusir penjajah dari Indonesia, dengan penerapan wajib militer di Indonesai tentu akan memberikan dampak yang sangat bermanfaat bagi jangka pendek atau jangka panjang terutama untuk para generasi bangsa yang akan memegang negara ini. Kehebatan suatu negara tidak hanya sekedar dari kepintaran ilmu pengetahuan namun juga pentingnya penanaman sikap cinta air. Penanaman sikap cinta tanah air tersebut dapat dilakukan seperti pemberian materi militer dengan mengadakan pelatihan pendidikan militer yang tercantum pada Undang-Undang No. 66 tahun 1958 L.N. No. 117/1958 tentang Wajib Militer, di dalam Undang-Undang Dasar ditegaskan bahwa pertahanan negara adalah kewajiban dan hak setiap warga negara, sifat pertahanan negara adalah pertahanan rakyat yang teratur dan diselenggarakan di bawah pimpinan pemerintah. ${ }^{23}$ Wajib militer ini dapat diperuntukkan untuk pelajar, mahasiswa dan terkadang pegawai kerja yang baru saja bergabung dengan suatu perusahaan. Pelatihan dasar militer ini untuk laki-laki maupun perempuan, namun untuk kaum wanita pelatihan yang diberikan tidak seberat kaum laki-laki karena dalam Undang-Undang No. 66 tahun 1958 L.N. No. 117/1958 tentang Wajib Militer pada Bab I pasal 2 mengatakan bahwa, "Mengikut-sertakan kaum wanita dalam dinas wajib-militer harus disesuaikan dengan kodrat serta sifat kewanitannya dan dengan taraf emansipasi wanita Indonesia atas dasar sukarela yang diatur dalam Peraturan Pemerintah", ${ }^{24}$ yang mengartikan bahwa dalam pendidikan dasar kemiliteran ada perbedaan pelatihan bagi kaum laki-laki dan wanita.

Penerapan wajib militer guna meningkatkan sikap cinta tanah air sering diterapkan dalam tingkat sekolah, perguruan tinggi serta dalam perusahaan. Sebuah sekolah atau perusahaan mengirimkan beberapa murid atau pegawainya untuk melaksanakan wajib militer yang dibimbing langsung oleh pihak tentara. Tentu pemberian materi warga sipil berbeda dengan seseorang yang memang sukarela mengabdikan dirinya untuk bergabung dengan salah satu angkatan bersenjata. Dalam RUU PSDN mengatakan jika calon komponen cadangan yang berasal dari unsur Aparatur Sipil Negara dan pekerja/buruh selama menjalani pelatihan dasar kemiliteran tidak menyebabkan putusnya hubungan kerja dengan instansi atau perusahaan tempatnya bekerja dan tetap memperoleh hak. Dan untuk Calon Komponen Cadangan yang berstatus mahasiswa selama menjalani pelatihan dasar kemiliteran juga tidak menyebabkan kehilangan status sebagai peserta didik dan tetap memperoleh hak akademis. ${ }^{25}$

\footnotetext{
${ }^{22}$ Chaidir Basrie. 1998, Bela Negara : Implementasi dan Pengembangan (penjabaran pasal 30 UUD 1945). Jakarta:Universitas Indonesia (UI-Press)., hlm. 15.

${ }^{23}$ Moch Faishal Salam, 1994, Peradilan Militer Indonesia. Bandung: Mandar Maju, hlm. 17.

${ }^{24}$ Kemenkuham, "UNDANG-UNDANG REPUBLIK INDONESIA NOMOR 66 TAHUN 1958 TENTANG

WAJIB-MILITER”, http://ditjenpp.kemenkumham.go.id/arsip/ln/1958/uu66-1958.pdf di akses pada 07

Desember 2019. 23.46.

${ }^{25}$ Muhammad Choirul Anwar, "RUU PSDN Usulan Jokowi Diketok, Ada Wajib Militer?", https://www.cnbcindonesia.com/news/20190926151713-4-102463/ruu-psdn-usulan-jokowi-diketok-ada-wajibmiliter Di akses 07 Desember 2019. 23.48
} 
Perwujudan keikutsertaan warga negara dalam pembelaan negar melalui pendidikan dasar militer atau wajib militer memiliki banyak manfaat yang dapat berguna untuk di masa sekarang dan masa depan. Pembekalan materi seperti Pengetahuan Senjata Ringan, Survival, Wawasan Kebangsaan, Pengetahuan tentang tataran Dasar Bela Negara, Peraturan Baris Berbaris (PBB), Peraturan Penghormatan Militer (PPM), Peraturan Urusan Dinas Dalam (PUDD), Navigasi Darat dan lain sebagainya, memberikan manfaat seperti berikut :

1. Pembentukkan karakter para generasi penerus bangsa. Pendidikan karakter adalah proses pemberian tuntunan kepada peserta didik untuk menjadi Manusia seutuhnya yang berkarakter dalam dimensi hati, pikir, raga, serta rasa dan karsa. Pendidikan karakter dapat dimaknai sebagai pendidikan nilai, pendidikan budi pekerti, pendidikan moral, pendidikan watak, yang bertujuan mengembangkan kemampuan peserta didik untuk memberikan keputusan baik-buruk, memelihara apa yang baik, dan mewujudkan kebaikan itu dalam kehidupan sehari-hari dengan sepenuh hati. ${ }^{26}$ Pada implementasinya upaya mendirikan negara relative lebih cepat dibandingkan membangun bangsa dan membangun karakter. Seperti halnya yang di katakana oleh presiden pertama Republik Indonesia, "Bangsa ini harus dibangun dengan mendahulukan pembangunan karakter (character building) karena character building inilah yang akan membuat Indonesia menjadi bangsa yang besar, maju dan jaya, serta bermanfaat. ${ }^{27}$

2. Menumbuhkan sikap bela negara. Pelaksanaan wajib militer dapat meningkatkan dan menumbuhkan sikap cinta tanah air, melihat pembekalan materi yang berupa penanaman nilai-nilai pancasila dan UUD 1945.

3. Indonesia juga bakal jadi negara yang disegani. Jika memberlakukan wajib militer, pertahanan Indonesia bakal semakin kuat. Indonesia memiliki penduduk yang sangat padat jika semua rakyat mendapatkan ilmu dari wajib militer maka akan banyak ditakuti oleh negara lainnya. Dengan begitu Indonesia tidak akan mudah untuk dijajah kembali oleh para penjajah atau negara-negara yang hendak menguasai Indonesia.

Menjadikan para pemuda Indonesia lebih disiplin. Kedisiplinan merupakan salah satu yang dibutuhkan untuk kemajuan bangsa. Melalui wajib militer, setidaknya kedisiplinan bisa ditanamkan pada jiwa-jiwa para pemudanya, yang diharapkan akan bisa diterapkan setelah selesai melaksanakan wajib militer. Jika kedisiplinan itu sudah mengakar pada para pemudanya, kemungkinan besar negara juga akan lebih tentram dan berkembang. ${ }^{28}$

\section{PENUTUP}

Bela Negara adalah sebuah konsep yang disusun oleh perangkat perundangan dan petinggi suatu negara tentang patriotisme seseorang, suatu kelompok atau seluruh komponen dari suatu negara dalam kepentingan mempertahankan eksistensi negara tersebut. Sebagai rakyat Indonesia membela negara sendiri sudahlah menjadi tanggungjawab bagi seluruh rakyat baik rakyat yang miskin ataupun kaya, kaum lelaki

\footnotetext{
${ }^{26}$ Muchlas Samani, Hariyanto. 2014, "Pendidikan Karakter". Bandung: PT REMAJA ROSDAKARYA, hlm. 45.

${ }^{27}$ Muchlas Samani, Hariyanto. 2014, "Pendidikan Karakter". Bandung: PT REMAJA ROSDAKARYA, hlm. 1

${ }^{28}$ Nikmatus Solikha, "5 Alasan Penting Kenapa Indonesia Harus Memberlakukan Wamil", https://www.boombastis.com/kenapa-indonesia-harus-wamil/101853 Di akses pad 08 Desember 2019. 00.09.
} 
ataupun wanita. Semua sama rata, dan memiliki hak dan kewajiban yang sama. Penerapan wajib militer yang sudah dilakukan di beberapa negara di dunia telah melahirkan orangorang yang setidaknya walau mereka tidak begitu ahli dalam hal perang, namun mereka tahu bagaimana sikap yang harus mereka tunjukkan untuk membela negara tercintanya. Pendidikan wajib militer ini memiliki banyak manfaat guna membentuk dan merubah para generasi selanjutnya untuk menjadi pribadi yang lebih baik lagi di masa yang akan mendatang. Karena sesungguhnya seseorang tidaklah harus hanya tahu tentang pelajaran saja tapi juga harus tahu bagaimana menjaga ketahanan wilayah negaranya jika suatu saat ada penjajah atau masalah datang.

\section{SARAN}

Penerapan wajib militer di beberapa negara di dunia patut dicontoh karena melihat remaja saat ini yang sudah lalai akan sejarah, serta membentuk karakter para generasi bangsa agar terciptanya Sumber Daya Manusia yang unggul dan berkarakter.

\section{DAFTAR PUSTAKA}

\section{Buku}

Muchlas Samani, Hariyanto. 2014, "Pendidikan Karakter". Bandung: PT REMAJA ROSDAKARYA.

Chaidir Basrie. 1998, Bela Negara : Implementasi dan Pengembangan (penjabaran pasal 30 UUD 1945). Jakarta:Universitas Indonesia (UI-Press).

Moch Faishal Salam, 1994, Peradilan Militer Indonesia. Bandung: Mandar Maju.

H. Ton Kertapati. 1988, Ketahanan Nasional Indonesia dalam Penerangan Pembangunan. Jakarta: PT. Pradnya Paramita.

Ben Fauzi Ramadhan, 2009, “Gambaran Persepsi Literatur” Jakarta: Universitas Indonesia, hlm. 8

\section{Internet}

Sybilla Narasya, "Apa yang dimaksud persepsi?", https://www.dictio.id/t/apa-yangdimaksud-dengan-persepsi/4669 diakses pada 07 Desember 201909.08

Khanza Savitra, "10 Persepsi Menurut Para Ahli", https://dosenpsikologi.com/pengertianpersepsi-menurut-para-ahli diakses pada 07 Desember 201909.10

Marolli, "Peringatan Hari Bela 2017", https://kominfo.go.id/content/detail/12075/peringatan-hari-bela-negara2017/0/artikel gpr Di akses pada 07 Desember 2019.18.48

Setjen Wantannas, "Bela Negara : Pengertian, Unsur, Fungsi, Tujuan Dan Manfaat Bela Negara”, https://www.wantannas.go.id/2018/10/19/bela-negara-pengertianunsur-fungsi-tujuan-dan-manfaat-bela-negara/ Di akses pada 07 Desember 2019. 18.49

Idtesis.com, "DEFINISI METODE DESKRIPTIF", https://idtesis.com/metode-deskriptif/ Di akses pada 07 Desember 2019.18.57 
Widya Yuridika: Jurnal Hukum, Volume 3 / Nomor 1 / Juni 2020

Kemenkuham, "SEJARAH BELA NEGARA", https://www.kemhan.go.id/belanegara/sejarah-bela-negara Di akses pada 07 Desember 2019. 22.45

CNN, "BPK Usulkan Menhan Segera Terapkan Wajib Militer", https://www.cnnindonesia.com/nasional/20190617140423-20-403904/bpkusulkan-menhan-segera-terapkan-di akses pada 07 Desember 2019. 22.49

Kemenkuham, "UNDANG-UNDANG REPUBLIK INDONESIA NOMOR 66 TAHUN 1958 TENTANG

WAJIB-MILITER", http://ditjenpp.kemenkumham.go.id/arsip/ln/1958/uu66-1958.pdf di akses pada 07 Desember 2019. 23.46.

Muhammad Choirul Anwar, "RUU PSDN Usulan Jokowi Diketok, Ada Wajib Militer?", https://www.cnbcindonesia.com/news/20190926151713-4-102463/ruupsdn-usulan-jokowi-diketok-ada-wajib-militer Di akses 07 Desember 2019. 23.48

Nikmatus Solikha, "5 Alasan Penting Kenapa Indonesia Harus Memberlakukan Wamil" https://www.boombastis.com/kenapa-indonesia-harus-wamil/101853 Di akses pad 08 Desember 2019. 00.09.

\section{Karya Ilmiah}

Rohmaul Listyana, Yudi Hartono,2015. "Persepsi Dan Sikap Masyarakat Terhadap Penanggalan Jawa Dalam Penentuan Waktu Pernikahan (Studi Kasus Desa Jonggrang Kecamatan Barat Kabupaten Magetan Tahun 2013)". Jurnal Agastya, Vol. 5, No. 1, hlm. 121 - 122. 